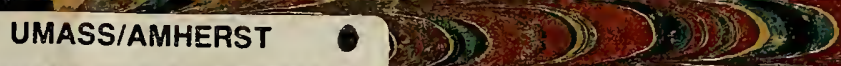

(n)

उ 12066005177603

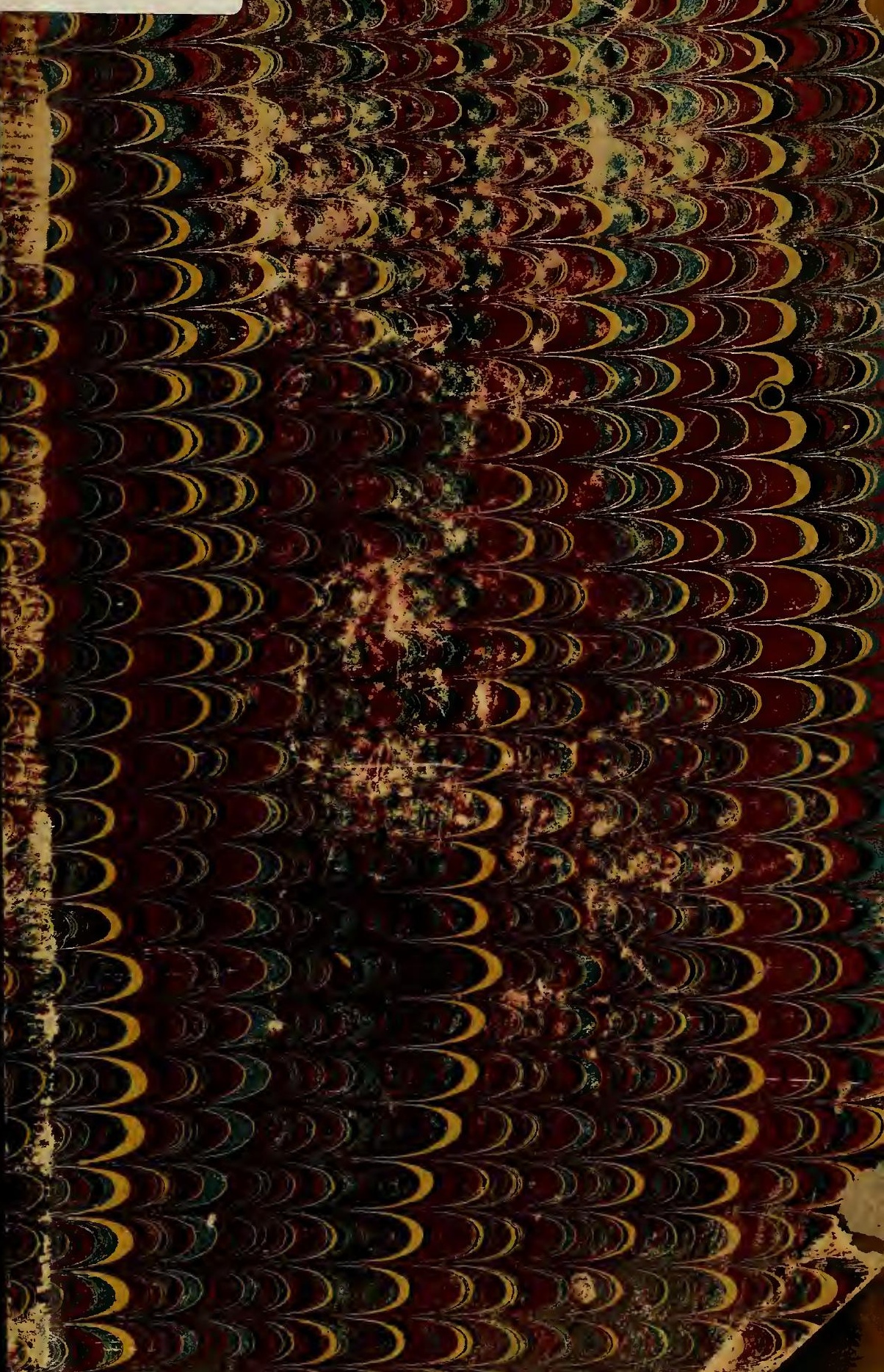




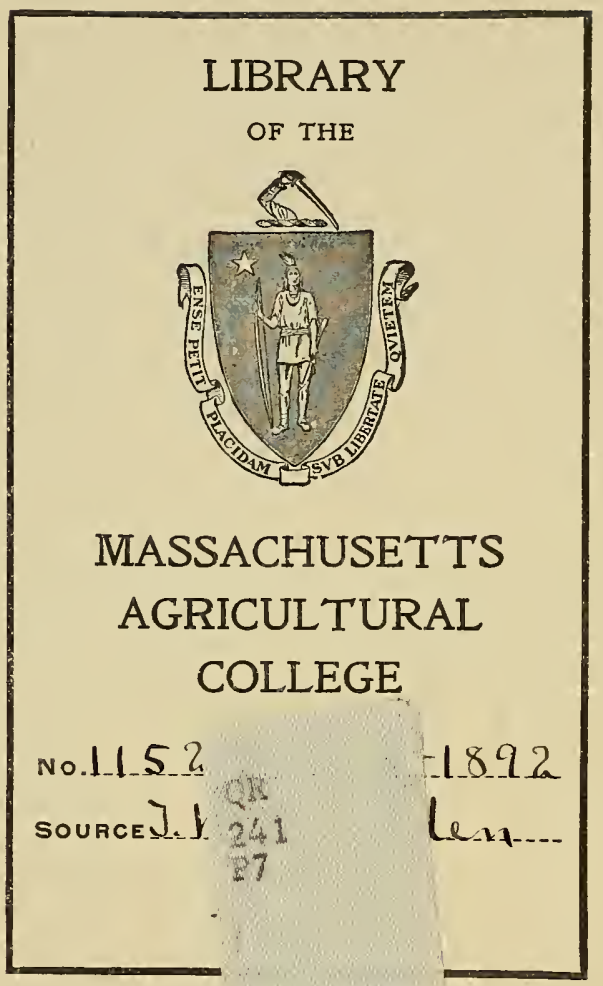


This book may be kept out

\section{TW O WEEKS}

only, and is subject to a fine of TWO CENTS a day thereafter. It will be due on the day indicated below.

\section{OCT 341904}

\section{OCT Lis ixus}







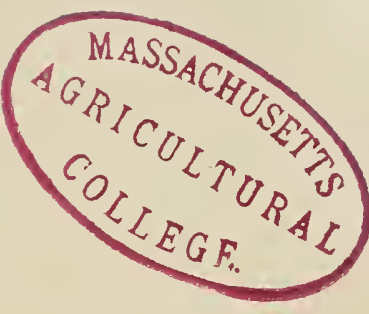



THE NEW YORK MEDICAL JOURNAL, JUNE 20, 1891.

ILLUSTRATING THE ARTICLE BY DR. PRUDDEN AND DR. HODENPYL.

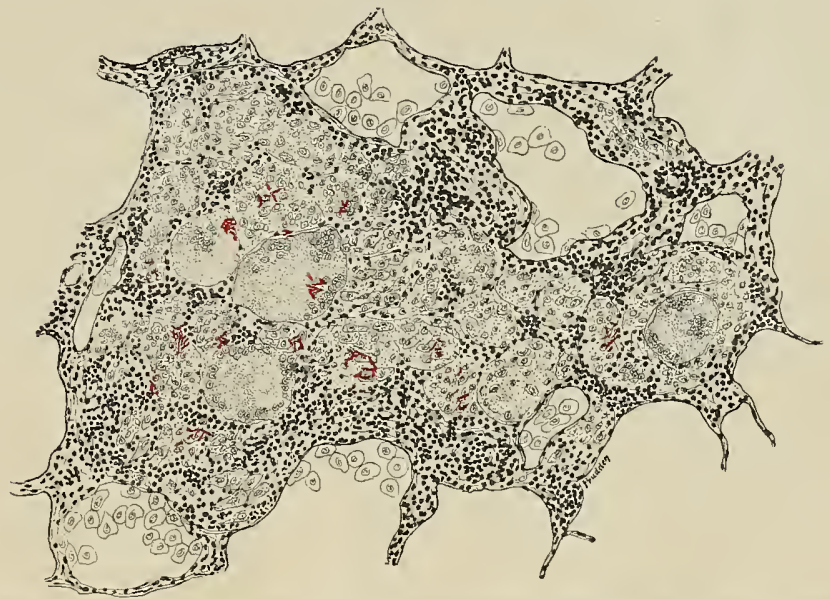

Fig, 1.-Nodule in rabbit's lung, ten days after intravenous injection of dead tubercle bacilli. Steamed three hours.

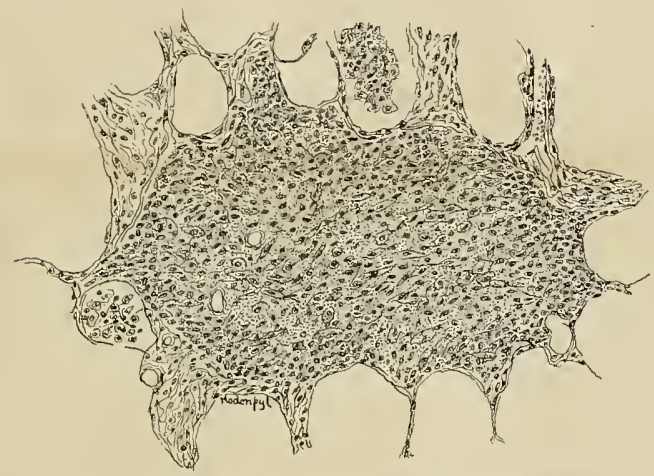

FIg. 2.-Nodule in rabbit's lung, twenty-eight days after intravenous injection of dead tubercle bacilli. Culture steamed two hours.

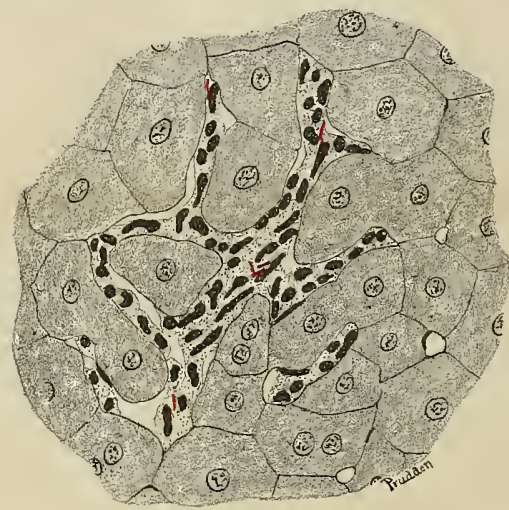

Fıg. 3.-New-formed cells in capillaries of the rabbit's liver, seventeen days after intravenous injection of dead tubercle bacilli. Culture steamed four hours.

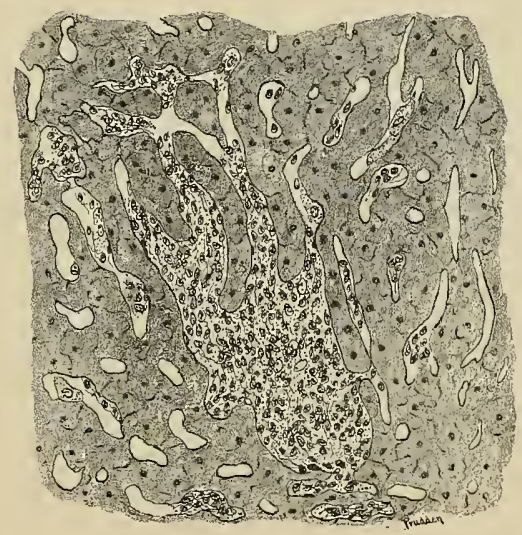

F1G. 4,-Diffinse cell-proliferation in vessels of rabbit's licer, twenty-five dass after intravenous injection of dead tubercle bacilli. Culture steauned an hour and a half. 
Digitized by the Internet Archive in 2010 with funding from

Boston Library Consortium Member Libraries 




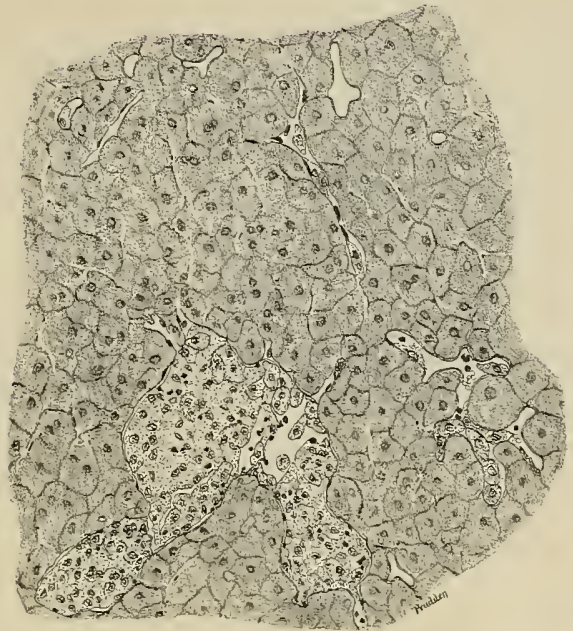

Fig. 5. - Small eircumseribed area of cell-proliferation in ressels of rabbit's liver. Same animal as in Fig. 4 .

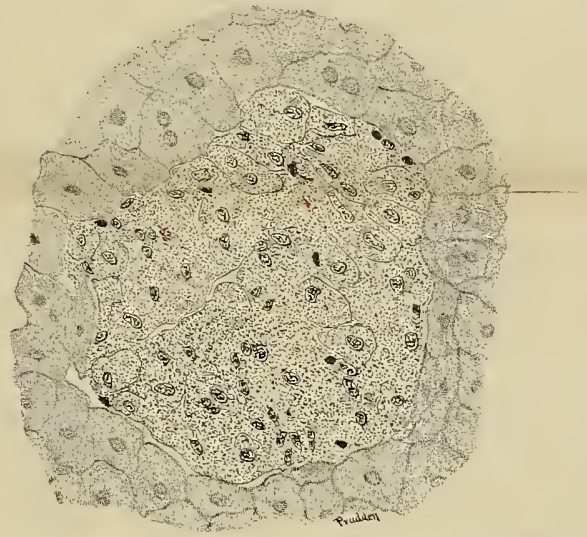

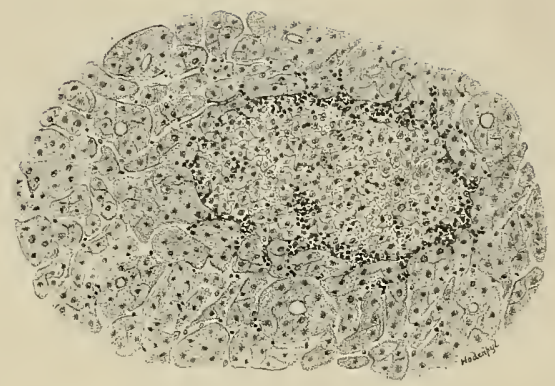

FIG. 6.-Small circumscribed epithelioid cell-nass in rahbit's liver, surrounded bs zone of small spheroidal cells, twenty-five days after intravenous injection of dead tuvercle bacilli. Culture briled an hour and a half.

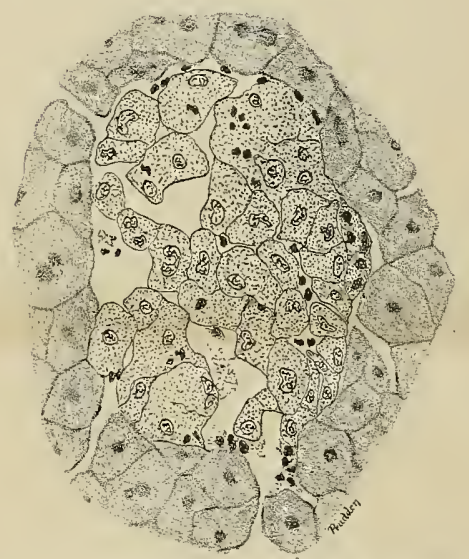

Fig. 8.-Small liver nodule composed of epithelioid cells. Same animal as in Figs. 6 and 9.

Fig. 7.-Small nodnle in rabbit's liver consisting of a mass of epithelioid cells, forty-eight days after intravenous injection of dead tnbercle bacilli. Culture steamed three hours.

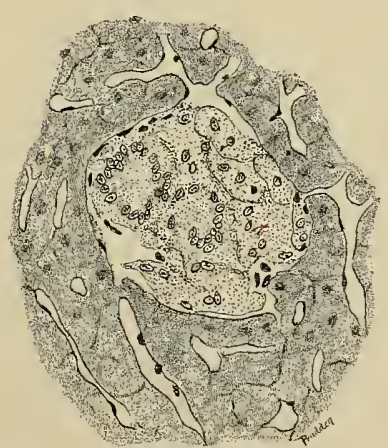

Fig. 9.- Todule in liver composed of epithelioid and giant cells. Same animal as in Figs. 7 and 8.

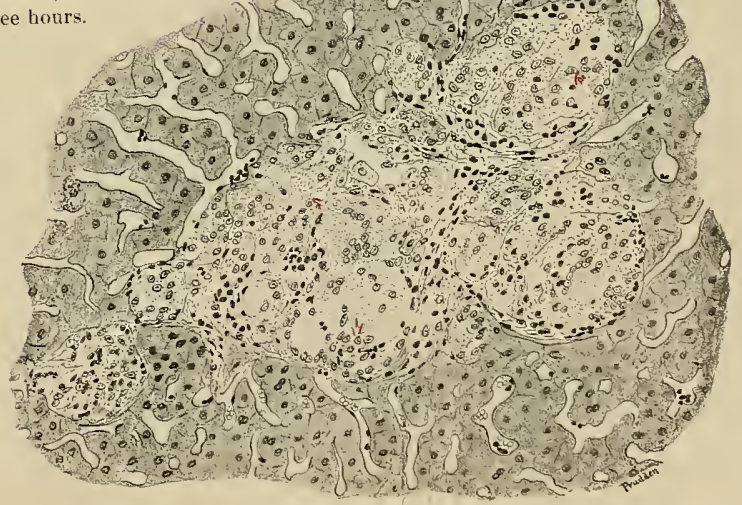

Fig. 10.-Complex nodule in rabbit's lirer, consisting of a congeries of epithelioid and giant cell masses, thirty-five days after intrarenons injection of dead tubercle bacilli. Culture steaned two honrs. Very few bacilli are remaining 



\section{STUDIES ON THE}

\section{ACTION OF DEAD BACTERIA IN THE LIVING BODY}

$\mathrm{BY}$

T. MITCHELL PRUDDEN, M. D.

DIRECTOR

AND EUGENE HODENPYL, M. D.

FIRST ASSISTANT IN PATHOLOGY IN THE LABORATORY OF THE ALUMNI ASSOCLATION OF THE COLLEGE OF PHYSICIANS AND SURGEONS, NEW YORK

First Paper.-Introductory

Segond Paper.-A Study of the Tubercle Baclleug

REPRINTED FROM

THE NEW YORK MEDICAL JOURNAL

FOR JUNE 6 AND 20, 1891

NEW YORK

D. APPLETON AND COMPANY 


$$
\begin{aligned}
& 577 \\
& 175=
\end{aligned}
$$

COPYRIGHT, 1891,

BY D. APPLETON AND COMPANY. 


\section{STUDIES ON THE ACTION OF}

\section{DEAD BACTERIA IN THE LIVING BODY.}

\section{First Article.-Introductory.}

Trie researches of the past decade, bringing to light, one after another, the specilic micro-organisms of some of the most common and fatal diseases, have been so surprising, so definite, so full of the promise of fruitful ontlooks upon hitherto untrodden fields, that we have scarcely yet had time to recover from the glamour of the new light or to realize, in the urgency of fresh practical problems, the exact extent and bearings of the new knowledge.

For a time it seemed enough, and even more than enougb, that month by month the proof grew stronger that anthrax and tuberculosis and typhoid and erysipelas and pneumonia and tetanus ancl diphtheria, and a whole group of allied "wound diseases" and others of the so-called "infections" class, were always associated with certain germs, each peculiar in its life history, ancl each standing, as we say, in an ætiological relationship to its particular disease.

But as we have little by little become accustomed to the new light, it has become evident not only that we are still ignorant about the relationship of micro-organisms to several extremely frequent and important infectious diseasesthe exanthemata, for example-but also that when we have learner that a given acute infections disease is always associated with a particular form of germ, when the life history of that germ is made out, and we can sar that it stands in an ætiological relationship to the disease, there yet remains a series of accessury problems to be solved in each particu- 
lar ease scarcely less important than the establisliment of the invariable association of the germ with the disease.

We are just beginning fairly to realize that the disease is not an entity, a thing imparted by the invading germ to the body, but that it is the result of the reaction of the hody cells in the presence of the germs; that the body-cell factor is just as important and just as inuch in need of study as is the germ-cell factor. We have been largely forgetful hitherto, as with painful detail the characters and preferences and metabolisms and vulnerabilities of the pathogenic germs have one by one been brought to light, that before onr knowlerige of the acute infectious diseases can be at all complete, the characters and preferences and metabolisms and vulnerabilities of the body cells must be subjerted to an equally careful scrutiny. The germ side of the problem is new and fascinating; the man side is old, and cellular pathology is a phrase familiar to our ears. But these old problems have become fairly new in their new light, and can not too soon be taken up afresh if our knowlerlue of the acute infectious diseases is to be symmetrical and of lasting use.

Partly by clinical observation and partly by laboratory studies is the new knowledge of the man side of this theme to be acquired, and old clinical observations, which have lain unintelpreted or misinterpreted, and new facts which the new points of view ean not fail to elicit, will surely be fast forthcoming.

But, returning to the bacterial side of the problem, it became evident, very soon after the definite status of pathogenic germs was made ont, that something more than their mere presence was necessary to account for the manifestations of the acute infections diseases.

The early discovery that certain pathngenic germs set free poisonous substances of one kind or another as the result of their life processes, and the evidence that these substances were direetly accountable for many of the manifestations of the acute infections diseases, drew attention to the complexity of the problems involved, called in the services of the physiological chemists, and for a time it seemed, and still does to many, that, after all, it was the poisons which the bacteria elaborated and sent out into the body 
on their destructive missions which was the most important thing. "Ptomaines" became a favorite word. When we had said that a given germ produced a given disease or effect by the elaboration of a given ptomaine, it seemed to many fairly unreasonable to ask for any further explanation of the acute infectious diseases. The germs were relegated to the more humble function of poison-factories, and the ptomaines were invested with the insignia of malevolent power. The pendulum seems disposed to swing back germward now, and in this paper, which is preliminary to the record of some experimental studies inade by Dr. Hodenpyl and the writer, and shortly to follow, on the tubercle bacillus, it is my purpose briefly to review a series of recent studies on the germ-cell bodies which throw a curiously interesting new light on some old borly.cell problems.

A very curions vital phenomenon which has long been known in certain unicellular organisms-such as the freshwater amoeha and in the leucocytes of both the cold and warm-blooded animals-is their response by movement to contact with solid substances. Thus the amœba floating free in fluids tends to assume a spheroidal form and to remain immolile. When, however, under suitable conditions, it touches a solid surface, like that of a glass slide, it sends ont psendopodia and performs those curious progressive evolutions known as the amœhoid movement. Essentially, the same series of movements is observed in leucorytes when they, under farorable conditions, come in contact with solid surfaces-such as a glass slide or the walls of the body lymph-spaces. This faculty in these primitive forms of life, consisting of a simple lump of protoplasm, is called tactile sensibility, and it is in virtue of this that many of the remarkable and useful evolutions of the leucocytes in the body transpire.

It was found by Pfeffer (1), a good while ago, that some of the lowly vegetable organisms endowed with locomotion -the Flagellata, Bacteria, etc.-were capable of moving toward or away from certain substances which exerted a cheinical action upon them. This property he designated as chenotaxis, and further postulated as positive chemotaxis the attracting effect, and as negative chemotaxis the repelling effect on such organisms of the chemical substances. 
Pfeffer has shown that mobile bacteria move toward nutrient substances, such as beef-tea, and Engelmann and others (2) have demonstrated their movement toward oxygen, both effects being apparently due to the positive chemotactic action of these substances. Stahl (3) showed that similar properties exist in the plasmodia of myxomycetes. This movement has been proved to be due, not to currents in the fluids, not to diffusion, but to the specific action of the particular chemical substances in question on living organisus.

The chemotactic powers of the juice of raw potatoes, which contains, as Pfeffer showed, potash salts and asparagin, has been used in capillary tnbes by Ali Cohen (4) to separate mobile from immobile bacteria in mixtures. In this way he found that he could separate cholera and typhoid bacilli from the numerous other forms in freces, and thus make easier the obtaining of pure cultures for diagnostic purposes.

Now, the same condition of affairs exists in the leucocytes of both the colr-blooded and warm-blooded animals, and the conditions and bearings in them of this positive and negative chemotaxis were studied in detail by Massart and Bordet (5) and by Gabritchevski (6) in 1890. The latter observer has grouped as the result of his experiments certain chemical substances in accordance with their action in this way upon leucocytes. Thus, in the group of substances exciting a neartive-repelling-chemotaxis, we have concentrated salt solution, 10 per cent.; lactic acid; quinine, 0.5 per cent.; alcohol, 10 per cent.; chloroform; jecjuirity ; glycerin; bile. Substances having no effect-indifferent chemotaxis-are distilled water; dilute salt solution, $0 \cdot 1$ to 1 per cent.; carbolic acid, 1-per-cent. solution; antipyrine; glycogen; peptone; beef-tea; blood; aqueous humor. Among the most prominent substances exciting a positive chemotaxis are especially sterilized and non-sterilized cultures of various pathogenic and non-pathogenic bacteria.

The general method of testing the powers of these various substances is to fill small capillary glass tubes, closed at one end, with the substance to be tested, and to thrust these beneath the skin of an animal. After a few hours 
these tubes are withdrawn and their contents examined. Into tubes filled with substances inciting positive chemotaxis the lencocytes crowd in great numbers, while they are held away from tubes having negative chemotactic contents, and when filled with indifferent substances there is no effect at all. While the tactile sensibility of leucocytes may cause them to cluster in small numbers abont the surface of the glass tubes, the effect of this property in the leucocytes is altogether insignificant as compared with the chemical substance exciting positive chemotaxis.

It appears, then, that there are certain substances associated with bacteria which excite in the lencocytes a movement toward the germs. The culture medium itself has no such effect, but the action is developed equally whether the cultures be living or have been killed by boiling. It would thus appear that either the bacteria themselves or some result of their life and growth must be the exciting agency.

Under the dominant views regarding the significance of the various chemical substances set free by bacteria as they grow, it has been assumed that it was largely under the ex citing influence of the ptomaines that leucocytes exhibited the phenomena of chemotaxis in the presence of bacteria. A practical bearing was given to the subject, under the influence of this view, by the assumption that in the process of suppuration, as commonly induced by various species of bacteria, the leucocytes gathering at the inflammatory foci were drawn thither in virtue of their chemotactic properties which the metabolic bacterial poisons brought into play. To this view the doctrine of phagocytosis, as held by Metschnikoff and his adherents, readily attached itself, and we had a well-rounded hypothesis, in accordance with which the leucocytes, drawn, in virtue of their chemotaxis, into the vicinity of invading bacteria, at once set to work to destroy them, and with them the poison sources which were stimulating excessive cell inroads.

But while these observations were going on, an allied but quite iudependent series of experinents was being carried out by Buchner and his associates in Munich, which have thrown a new and apparently most significant light upon both the phenomena of chemotaxis and the nature 
of suppuration. To these experiments let us then briefly turn.

While it is fully established that a true suppurative inflammation may be experimentally induced by a variety of inorganic substances, it is still true that the suppurative processes which occur in the body, either as independent lesions or as complications of a variety of diseases, are practically always due to the action of bacteria. So that in a clinical sense the summary statement, "no suppuration withont bacteria," is true. While, as above indicated. it has been the general belief of late that the metabolic products of bacterial life, the "ptomaines" or the "toxines," were the active agents in inducing suppuration, this, save in a few instances, has not been proved.

Buchner (7), in the course of some experiments on the introduction of anthrax spores and anthrax bacilli into the trachea of rabbits and guinea-pigs, had observed some time ago that while the introdurtion of the hacilli was followed by an intense inflammatory reaction of the lung tissue, with accumulation of leucocrtes, fibrin, etc., in the air spaces, the introduction of the spores alone was followed by no such marked inflammatory reaction, but that the spores entered the blood channels and induced, in due time, the usual systemic effects of anthrax poisoning.

There is one factor-so reasoned Buchner-which has not been taken definitely into the account in the causation of suppurative inflammation by bacteria, and that is the possibility that the effect may be produced, not by the ptomaines, not by the toxines already so much studied, but by the albuminoid constituents of the bacterial cells themselves. If this were true, then the intense exudative inflammation in the lungs following the introduction of the anthrax bacilli might be explained by the local disintegration of the bacilli and the setting free of their potent proteid constituents, while no such effect would follow the introduction of spores.

It has been repeatedly shown by numerous observers (8) that sterilized cultures of various progenic bacteria-such as Staphylococcus pyogenes aureus, Bacillus pyocyaneus, etc.were as capable of producing suppuration as were the fresh living cultures. But it was believed that this was due to 
the retention of a toxic substance furnished by the life processes of the germ which had wot been destroyed by the sterilization, but clung about the read germ bodies. Although Wyosokowitsch had filtered off the fluid from sterilized anthrax cultures and found that the filtrate was not pyogenic, while the solid material was, he inferred only that the toxic material assumed to cause suppuration was not soluble in the nutrient fiuid.

Buchner had also shown (9), in the course of some other experiments, that the sterilized emulsion of the so-caller pnenmo-bacillus of Friedlander, subcutaneonsly injected, conld eanse suppuration in rabbits and guinea-pigs. He found further that if such a sterilized emulsion were allowed to stand for some time, so that the solid could be separated from the fluid parts of the mass, the fluid part did not cause suppuration, while the solid part did. That the effect of such sterilized bacterial emulsions was not due to their mechanical effects in the tissues was shown by such control expcriments as the introduction of powdered charcoal, infusorial earth, magnesia, potato emulsion, etc., beneath the skin, with negative results.

By a series of manipulations similar to that practiced with the pnellmo-bacillus, Buchner now tested the effect of sterilized emnlsions of cultures of seventeen different species of hacteria, among which may he mentioned Staphylococcus pyogenes aureus, Staphylococcus cereus flavus, Sarcina aurantiaca, Bacillus prodigiosus, Bacillus fitzianus, Bacillus cyanogenus, Bacillus megatherium, Bacillus subtilis, Bacillus coli communis, Bacillus acidi lactici, Bacillus anthracis, Proteus vulgaris, Finkler's comma bacillns, etc. The injection of one cubic centimetre of the sterilizer emulsions of each of these germs resulted within two to three days in an aseptic-that is, bacteria-free-purulent infiltration in the subcutaneous tissue at the seat of injection. On the other hand, the clear fluid obtained by sedimentation from the sterilized emulsions of Bacillus cyanogenus, Bacillus megatherium, and Bacillus anthracis, induced no suppuration, while the separated sediment invariably did.

While it thus seemed probable that the albuminous material of the hacterial cell was at least chiefly concerned in inducing suppuration on the injection of sterilized emul- 
sions, this was not yet fairly proved. Buchner now songht to strengthen the evidence by a very ingenious experiment. The modern technique of staining bacteria with the aniline dyes depends, as is well known, upon the power of these dyes to enter into chemical combination with the bacterial cell plasma. Acting upon this principle, Bnchner found that if he added to a sterilized emulsion of the pneumobacillus, which was strongly pyogenic, an aqueous solution of methyl violet, the emulsion was wholly bereft of its progenic powers. Anent of this interesting bit of evidence of the importance of the bacterial cell proteids, Buchner calls attention to its bearing upon the thenry of the antiseptic and antipsogenic action of the so-called pyoktanin of Stilling, the usefulness of which in practice is still sub judice.

But more definite proof of the importance of the bacterio-protein in indncing suppuration was still nceded, and Buchner proceeded to separate it from cultures of the pneumo-bacillus after the method of Necki, by digestion of masses of culture in dilute potash and precipitation with acetic or hrdrochloric acid. The precipitate separated by filtration was again dissolved in dilute potash solution and reprecipitated. This was done the third time, and at last the purified product was brought into solution. This material gave the chemical reaction of an albuminoid body. Subcutaneous injection of this material in rabbits in some cases was followed by a gathering of leucocytes, in others not. As it seemed likely that on simple subcutaneous injection the naterial was readily and rapidly absorbed before it produced local effects, reconrse was bad to a method of experiment used by Councilman in his well-known studies on suppuration (10). Small glass tubes, drawn out at the ends, were filled with the pneumo-bacillus protein, sealed up, and sterilized by stean for an hour. These were then introduced, with strict antiseptic precautions, beneath the skin of rabbits, shoved away from the opening, and, after they were healed in, their tips were broken off. After five dars the tubes were exposed. Around the openings of these, as well as extending deep into their interior, were masses and plugs of leucocytes. Cultures showed no living bacteria.

- Control experiments with tubes filled with salt solution showed no collection of lencocrtes. 
It thus seemed to be proved that the pyogenic action of sterilized cultures of Friedlander's pnenmo-bacillus is due to the freed albuminoid constituents of the bacterial cell. That such a freeing of the contents of the bacterial cells occurs in the tissues of the living bodr seems evident from their well-known proneness to disintegration and the development of involution forms in suppurative foci.

The next thing to be done was to carry on a similar series of experiments with other well-known pathogenic bacteria. To this task Buchner and his associates adrressed themselves in a series of studies as yet not fully pollished (11). But, evell so far as their results are knoin, some most significant facts have been elicited. Bnchner endearored to separate by the method of Necki (see above) the bacterio-protein from about fifteen species of bacteria, but in many of these the attempt was unsuccessful, hecause sufficient solution and extraction of the proteid ingredients of the germs did not occur. The Bacillus pyocyuneus gave the most abnndant albuminous extract, but a sufficient amount was obtained from Staphylococrus pyogenes aureus, Bacillus typhosus, Bacillus subtilis, Bacillus acidi lactici, and from the red potato bacillus for animal experiment. It was, in fact, found that capillary tubes filled with the purified proteids from all these species of bacteria and placed beneath the skin of the rabbit showed after two or three days, extending into the open end, a plug of fibrinous pus several millimetres in length. This plug was found, on microscopical examination, to consist largely of lencocytes.

That the ordinary chemical decomposition products of bacterial cell life are not concerned in inducing this positive chemotaxis in the lencocytes was shown by introducing beneath the skin of rabbits tubes filled with snch substances as butyrate and valerianate of ammonia, trimethylamin, ammonia, glycocoll, leucin, tyrosin, urea, etc. These were, for the most part, wholly without effect upon the leucocytes, only glycocoll and leucin exciting in some cases a moderate chemotaxis, not at all to be compared, however, with that of the hacterio-proteins.

It would thus seem to be highly probable, if not absolutely proved, that the power of exciting positive chemotaxis, which at least many species of bacteria display, is 
due to the proteid ingredients of their bodies when these are set free, as they may be naturally when the germs disintegrate in the tissues, or artificially by chemical extraction.

With that keenness and fertility of thought which characterizes Buchner's work, he now gave wider range to his investigation. He recognizerl the faet that, though of late the phagocytic action of the leucocytes has been especially emphasized in relation to bacteria, this is by no means their chiefest or most constant rôle. Dispose of bacteria the lencocytes undoubtedly do; whether after themselves killing them, or after they are destroyed by other agencies, has not yet been fully detcrmined. But by far the most constant phagocrtic rôle of the leucocytes is in carrying on the process of resorption and disposal of useless particles and dead material in the living body. About such material they gather much as they do in the vicinity of bacteria, though not in such marked degree or under such dramatic conditions.

Now, what attracts the lencocytes into the vicinity of a particle of dear and useless muscle, or cartilage, or connective tissue which they are to absorb and remove? Certainly not bacterial poison, certainly not bacterial proteids, for with what may be called the normal phagocytic functions of the leucocytes bacteria have nothing to do. Having shown that a proteid substance derived from the bacterial cells was capalle through chemotaxis of attracting leucocytes, Buchner now studied in a similar way the effects of closely allied snbstances-namely, the so-called regetable caseins, gluten casein from wheat and legumin from peas, both separated by precipitation from alkaline solutions. Both of these substances were capable of exciting the most marked chemotaxis in the leucocytes of rabbits. Moreover, as it has been shown that vegetable casein exists as such in the grain of cereals and of the leguninosæ, he introduced beneath the skin of rabibits or guinea pigs, under strict antiseptic precantions, masses of wheat and pea meal, and found that within two days these masses were surronnded and penetrated by enormous masses of leucocytes. Cultures from these masses proved the entire absence of bacteria. Starch introduced subcutaneonsly under the same conditions induced no gathering of lencocytes. 
That this gathering of leucocytes was due to chemotaxis and not simply mechanical, owing to the tactile sensibility of the leucocytes, was shown by introducing subcutaneously in a rabbit in one place an emulsion of infusorial earth with 0.7 -per-cent. salt solution, and in another place an emulsion of the earth with glutin casein. In the first, after three days, lut few lencocytes had gathered about the foreign material, while the second was surrounded and partially penetrated by an inormous number of lencocytes.

But still another step remaincd to be taken. As the gatbering of leucucytes about dead organic fragments in the tissues which are to be removed, as so often happens, can not be ordinarily due to bacteria or bacterio-protein, so, also, intcresting as the observation may be, can vegetable proteins have no part in the matter. So alkali albuminates were prepared and purified, in a manner similar to that employed with the bacterial and other regetable proteins from muscle, liver, lungs, and kidney of rabbits. These tested in the same way were all found to strongly attract lencocytes when introduced beneath the skin in tubes. Of the alkali albuminates prepared from blood, fibrin, jolk and white of egg, only the blood and yolk of egg showed moderate power of exciting positive chemotaxis.

These experiments show that it is only certain of the decomposition products of animal tissue which possess cliemotactic powers, and that these, as a rule, are the earlier and not the ultimate products of the decomposition.

Finally, as it has been shown that a general leucocytosis is apt to be associated with febrile inflammatory processes, Buchner and Roemer studied the effects of intravenous injections in rabbits of these various chemotactic proteids. They found that within eight hours of their introduction into the blood there was a marked leucocytosis lasting for several hours, and that this might be heightened by repeated injections. Thus they found, by a daily injection of 2 c. c. of an eight-per-cent. solution of the bacterio-proteins of $\mathrm{Ba}$ cillus pyocyaneus, the relation of white to red blood-cells, which at first was 1 to 318 , was on the second day 1 to 126 ; on the third day, 1 to 102 ; on the fourth morning, 1 to 73 ; and on the same erening, 1 to 38 . From this time on no 
increase was noted. The absolute number of the red blond-cells remained unchanged, while there was an absolute sevenfold increase in the number of leucocytes. Gluten casein, as well as alkali albuminate from muscle, injecter into the blood, showed similar but less pronounced effects.

Considering now the bearing of all these experiments on suppuration and on physiological resorption of dead organic materials in the tissues, it wonld appear that in simple resorption, as in bacterial suppuration, the leucocytes are drawn to the seat of operation by a proteid material. This in resorption seems to be furnished by the dead and disintegrating tissues themselves, and when the leucocytes have gathered up a ccrtain amount of refuse in their boclies they may carry it away. In hacterial suppuration, on the other hand, the attracting material may be furnished by the protein of the disintegrating bodies of the bacteria themselves, but poisonous ptomaines fuınished by the live bacteria may cause the destruction and degeneration of the attracted leucocrtes, which thins collect as pus.

Whether the ptomaines themselves may not indirectly furnish chemotactic material by causing the destruction of the tissue elements and the setting free of their albuminous constituents, is a matter requiring further study.

It is also not improbable that the limited suppuration induced by bacteria-free chemical substances-such as turpentine, calomel, etc.-may be due to the chemotactic tissue-proteids set free by the action of the chemicals on these tissues.

It seems probable that not only are the lencocytes drawn toward the chenotactic proteids thus produced in or introduced into the body, but that the fixed connective-tissue cells are stimulated to proliferation. In fact, Buchner found that by the introduction of a sterilized emulsion containing 3.5 milligrammes of pyocyaneus protein into the forearm of one of his associates, a severe inflammation was induced with all the symptoms of an acute typical erysipelas, with lymphangeitis, such as must have involved the fixed connective-tissue cells. On the fourth day the inflammatory process underwent resolution. Gluten casein induced similar but less acute effects. 
These most clever and striking researches of Buchner would seem to throw much light on the whole sulject of the theory of suppuration, and to promise large accessions to our knowlerge of inflammation when the many lines of thought and study which ther suggest shall have been followed out.

It is now evident that an aseptic suppuration is possible under a rariety of conditions.

It still remains true, however, for the purposes of surgical practice, that the suppurative processes as we see them in the clinic and at the bedside are due to the presence of bacteria of one form or another. It is true, also, that the suppurations which we can induce experimentally with sterilized - that is, dead-bacterial cultures. or with certain dead proteid substances-aseptic suppurations-are limited in their duration, extent, and destructive power, as compared with those occurring under the influence of living germs. This is becanse in the latter case the growing and new forming germs may keep up the inflammation once alight to an almost indefinite extent.

We purpose, in the paper which is to follow, to detail some results of a series of experiments on the action of dead tubercle bacilli on the living tissue not less striking than are those which show the power of other sterilized bacteria to induce suppuration.

\section{Bibliography.}

1. Pfeffer. Unters. a. d. botanischen Institut zu Tübingen, 1886-1888.

2. Engelmann. Bot. Zeitg., 1881. Prndden. Medical Record, March 26, April 2, 1887.

3. Stahl. Zur Biologie der Myxomfreten. Bot. Zeitg., 1884.

4. Ali Cohen. Ctrlbl. für Bakteriologie, Bd. viii, I890, No. 6, p. 165 .

5. Massart and Bordet. Journal pullié par la soc. royale des sciences médicales et naturelles de Bruxelles, 1880, v.

6. Gabritchevski. Annales de l'inst. Pasteur, June 25, 1890.

7. Buchner. Berl. klin. Woch., 1890, No. 30, p. 673.

8. Buchner. Op. cit., p. 674 .

9. Buchner. . Berl. klin. Woch., 1890, No. 10.

10. Councilman. Virchow's Archiv, Bd. 92, 1883.

11. Buchner. Berl. klin. Woch., 1890, No. 47. 
Second Artiole.-The Aotion of Sterilized Cultures of the Tubercle Bacillus.

$W_{E}$ liave seen in the first article (1) that the action of bacteria in the body is by no means linsited to the changes induced by those substances called ptomaines and albumoses, or toxalbumins, which are set free by living germs. It appars that the proteid constituents of the bacterial cells themselves, when these are set free, either by a natural disintegration of the germs or by an artificial extraction, are capable not only of stimulating the fixed body cells to proliferative changes, but may, by calling into play the forces involved in chemotaxis, cause either a moderate collection of leucosytes or induce marked suppuration.

It is probable that these two fairly distinct factors, the eliminated ptomaines and albumoses on the one hand, and the bacterio-proteins on the other, are both involved in many, if not most, of the acute infectious diseases. But one or other of these factors is apt to be so preponderant in many cases as to fairly dominate both the symptoms and lesions.

For example, in tetanus, typhoid fever, and Asiatic cholera, the toxic substances absorbed into the body at large from the seat of growth of the pathogenic geruns may determine profound and even fatal symptoms without much local change at the proliferating germ centers.

On the other hanıl, in many of the local suppuratiousin pneumonia and in tuberculosis, for example-the uost marked effects are apt to be induced in the immediate vicinity of the invading germs.

In still other diseases-diphtheria, for example-we may have extreme local tissue changes together with profound systemic effects.

Finally, under a variety of unusual conditions, pathogenic germs which commonly induce one particular order of lesions may bring about most striking alterations of another class.

As an example of this variability of effect, we may cite 
the suppurative inflammations which not infrequently occur as complications of typhoid ferer, when these germs lodge or grow in unusual situations.

Perhaps the most striking example of a pathogenic germ wlose effects are closely limited to the immediate neighborbood of its seat of growth is the Bacillus tuberculosis. That there may be systemic effects inducerl by the absorption into the body at large of poisons eliminated by the tubercle bacillus, we, of course, can not deny. But if such there be, we certainly know very little abont them, and they must be insignificant in comparison with the dominant lesion of tuberculosis-namely, the production immediately about the germs of a new short-lived tissue having a moderately characteristic morphology and prone to undergo degenerative changes of great significance, both to the germs which cause it and to the integrity of the invaded organ.

It is because of the peculiarly direct and constant relationship between the germ and the lesions which it induces that we have selected the tubercle bacillus for an experimental study along the lines which our preliminary paper has suggested.

But, before detailing our own experiments, it seems desirable to briefly notice some observations already made in this field, which will have a bearing in establishing our point of view.

A number of studies have been made on the metabolic products set free during the growth of the tubercle bacillus both in cultures and in the body. But these studies have been made from such a variety of different standpoints and with such different technique that it is difficult to glean any very positive and definite data from the results.

Hammerschlag (2) founil in the alcohol and ether extract of the trbercle bacilli, fat, lecithin, and a poison which induced spasms and death in rabbits and guinea-pigs. The residual material of the bacilli contained an albuninoid and cellulose. He could not separate a ptomaine by Brieger's method, but did find evidence of a fever-causing toxalbumin.

The recent publications of Koch on the nature and effects of substances in or derived from cultures of the 
tubercle bacillus we may assume to be familiar to all our rearlers. But the manner in which they have been made known and the lack of detail in the description of the mode of preparation of his "lymph" leave his results in a most unsatisfactory state of indefiniteness, so far as the scientific bearing of the subject is concerned. Some substance or substances, it would appear, either set free during the growth of the tubercle bacilli or, as it is said, extracted from them by glycerin, are capable of exerting rather illunderstood effects upon tubercle tissue in the body and are not without extreme effects in many cases upon the body at large. With the therapeutic bearing of the substances contained in Koch's tuberculin we have bere nothing to do.

One point, however, in Koch's last publication on this subject has an important bearing upon the subject in hand -namely, the statement that pure cultures of the tubercle bacillus killed by boiling, or in other ways, are capable of inducing local suppuration with no other effects, if introduced subcutaneously into the gninea-pig.

Hueppe and Scholl (3) cultivated the tubercle bacilli in a glycerin-peptone bouillon, and found that the fluid contained substances having essentially the same effects upon animals as those noted by Koch. As the result of an interesting series of experiments, these observers came to the conclusion that the specific poison of Koch's "lymplı" did not belong to the proteins, but to some substance or substances eliminated by the bacilli during their growth and contained in the culture fluils, and which were not, as Koch asserted, extracted from the culture by glycerin. Hucppe and Scholl separ:ated from the "lymph" which they bad prepared, and which seemed to be practically identical with the "lymph" of Koch, by precipitation with alcohol, a substance which appears to contain the active ingredient of the "Iymph." They separated in the same way the same substances from Koch's "lymph," and, on testing these in tubes bencatls the skin of animals, they formul that in both cases this substance was markedly chemotactic.

That Koch's "lymph" is not, as it is furnished in the crude condition, chemotactic and does not tend to cause abscesses, may be due to the fact that it contains glycerin, 
which exerts an influence on the leucocytes opposite to that. which positive chem tactic substances display.

Trudean (4), working also with fluid cultures, obtained materials apparently the result of metabolic processes of the tubercle bacilli which induced toxic effects upon animals. But these were not marked, since be did not succeed in sufficiently concentrating the fluid containing the materials songht for.

Zulzer (5) extracted from agar cultures a substance which, on purification and injection subcutaneously in small quantities into rabbits and guinea-pigs, caused temporary increased rapidity of respiration and an elevation of temperature. Larger does were fatal.

Crookshank (6) separated the bacilli from gl scerin-broth cultures by filtration, and concentrated the filtrate by evaporation. This concentrated filtrate, injected subcutaneously into guinea-pigs, induced muscular spasms, a lowering of the temperature, and death.

Weyl (7) extrarted tubercle bacilli with dilute caustic soda, and found in this extract a substance which seemed to him to belong in the mucin group. Subcutanenus injection of a solution of this substance produced in animals a local necrosis at the seat of injection.

Maffucci (8) found that sterilized cultures of tubercle bacilli introduced beneath the skin of gninea-pigs in considerable amounts were capable of inducing a chronic poisoning of the organism, ending in deatb from marasmus and great destruction of the red blood-cells in the spleen, hut does not note any marked local changes beyond the producing of an abscess.

Wyssokowicz (9) killed the tubercle bacilli in cultures by boiling, and these on subcutaneous injection in a rat caused a small local abscess, containing well-formed and readily stained though dead tubercle bacilli.

An emulsion of a boiled culture of the tubercle bacilli was injected into the abdominal cavity of a rat. The animal was killed on the thirtieth day. A few small nodules were found beneath the liv' $r$ which consisted of a central pus-like mass surrounded by a thin new-formed tissue wall. The central portion of these nodules consisted of tubercle bacilli and leucoç̦tes, while their walls were com- 
posed largely of endothelial cells, with here and there giant cells among them. Readily stained tubercle bacilli were scattered through the walls of these nodules, and the epithelioid and giant cells were often grouped about them. The microscopical examination of the liver revealed numerous small spheroidal nodules composed of epithelioid cells and lencocytes, among which were scattered a few tubercle bacilli.

We know that various kinds of substances, organic and inorganic, when introduced into the body, can become surrounded by a tissue in many respects resembling tubercle tissue. This was abundantly shown in the years just preceding the discovery of the tubercle bacillus and the final estahlishment of tnberculosis as an acute infectious disease. Whether the dead tubercle bacilli in these experiments of Wyssokowicz's act in some special way in stimulating the tissues to these tubercle-like growths, or whether they do this simply as foreign bodies, must be shown by further studies.

The action of the living tubercle bacillus in inducing the local lesions of tuberculosis scems to be quite complex. But there appear to be several tolerably distinct classes of influences at work.

In the first place, there seems to be an irritation or stimulation of the tissues near the bacilli which results in the proliferation of cells, primarily and notably of the connective tissue cells. The effect of this is to produce what is called the epithelioid cell tissue. Following this, or associated with it, there is a local action either on the leucocytes or the blood-vessels, or both, which leads to the accumulation of small spheroidal cells either in the periphery of the tubercle or distributed through it. Generally there is a necrotizing action which results in the coagulation necrosis or cheesy degeneration of the new-formed tissue or other tissne near the tubercle.

The giant cells which form such striking features in many phases of tuberculosis appear to be formed under the influence, on the one hand, of those factors which induce cell proliferation, and, on the other, of those which retard the completion of the cell proliferation when once it is under way. The impulse to cell division under these cir- 
cumstances is in so far successful that a protoplasmic mass is formed with many nuclei, but the consummation of this attempt, the division of the cell bodies, is in abeyance.

In view of the new facts regarding the singular power of the bacterio-protcin and chemotaxis which the researches briefly summarized in our first article have revealed, and the promising but, it must be confessed, rather obscure light which the recent studies on the poisons of the tinbercle bacillus have elicited, it has seened to us that some further studies on the tubercle bacillus should he made with the view of learning, if possible, in more detail something of the factors which are concerned in developing the complex structures which we call tubercles and tubercle tissue.

Our first series of studies was made with the view of determining what effects, if any, are produced in the body of the rabbit by the introduction of cultures of the tubercle bacilli killed by prolonged boiling and freed from any material elaborated by them during their growth on the artificial culture media, so far as such substances are soluble in the culture media, or in water, or in fifty-per-cent. glycerin. That is to say, we wished in these cxperiments to learn whether the dead bodies of the tubercle bacilli alone, apart from any of their elimination or soluble metabolic products, produced changes in the body cells of living rabbits, and, if so, of what kind.

Technique.-We cultivated the tubercle bacillus for this purpose on peptone agar with six-per-cent. glycerin, and in glycerin-peptone bouillon. In all cases we continued the growth until it became voluminous, and we obtained identical results whether the cultures were two months or six months old, and whether they were made in bonillon or on agar. We bave used cultures of tubercle bacilli derived from three different sources.

The solid masses of culture were scraped carefully off from the agar, or filtered from the culture-bouillon. In some cases we were not particular to remove from the cultures what culture-bouillon clung to the germ masses. But in most of the experiments the masses of bacilli were washed with sterilized distilled water, and then boiled in a 
small amount of sterilized water for from an hour and a half to four hours. In still another set of experiments we first carefully washed the culture masses, and then boiled them for from two to four hours in tifty-per-cent. glycerin with water, and then filtered off the fluid, washing the germ masses before making an emulsion with pure water for injection.

We have found that the condensation fluid in glycerinagar cultures and also the glycerin bonillon in which the tubercle bacilli had grown, when dropped into strong alcohol, gives a white precipitate, which, according to the studies of Koch (10) and Hueppe and Scholl (11), contains the active principles of Koch's tuberculin. We furthermore found that after the glycerin-agar condensation water or the glycerin bouillon in which the tnbercle bacilli are grown has been carefinly washed out of the culture masses of bacilli, no more of this tuberculin-containing material is extracted from the bacilli by either water or fifty-per-cent. glycerin, even after boiling for four hours. It would thus appear that the active substance in Koch's "lymph" is a material elaborated by the life processes of these germs and set free in the culture media, as shown by Hueppe and Scholl (3).

After steaming the bacilli for from an hour and a half to four hours in the steam sterilizer, and separating them from their metabolic products in the manner described, we have made an emulsion of the bacılli in sterilized water which we have used in our experiments. In a few cases we have boiled the bacilli togetl,er with a small amount of the culture fluds containing their metabolic products, but the results of these experiments have been the same as when we have carefully separated them.

We find that after prolonged boiling, either in water or in fifty-per-cent. glycerin, while many of the bacilli present the usual bizarre broken granular involution and degeneration forms so often described, most of them preserve their form intact, and are stained in the usual way by the KochEhrlich method. The broken granular forms are readily stained.

We have, by a series of separate experiments, proved that the tubercle bacilli are certainly killed by the pro- 
longed steaming to which they have been subjected, of from an hour and a half to fonr hours.

As this is, of course, a point of vital importance in onr experiments, we have been very careful about this preliminary sterilizing. We have used the Arnold steam sterilizer, which is one of the most efficient forms of laboratory sterilizers known to us. The inaterial to be killed bas been in rariably placed in small, thin-walled flasks, exposed to the full action of live steam. The duration of the steaming was, of course, carefully reckoned from the time when the chamber of the steamer and its contents was at the full boiling temperature. While we have found in a series of preliminary experiments that an hour and a half's steaming sufficed to kill the cultures, as, from what we know of the vulnerability of these germs, it should, in all except one set of experiments, we continued the steaming from two to four hours, the average time being about two hours and a half.

The masses of tubercle bacilli thus steamed have been proved to be dead, first, by their failure to grow on favorable culture media; and, second, by the much more delicate test of repeated inoculations in guinea-pigs, which invariably gave negative results so far as the development of tuberculosis is concerned. Finally, we have inoculated guineapigs with materials from the lesions about to be described as induced in rabbits by the dead cultures, and obtained in the guinea-pig only negative results.

In these ways we have satisfied ourselves that the material which we were using contained in every case no living tubercle bacilli, but only their dead bodies.

Experiments. - Subcutaneous Injections. - We first made a series of injections of the emulsion of the sterilized tubercle bacilli in rabbits beneath the skin and found that in a considerable proportion of cases a small local abscess is developed in from two to six weeks. This abscess, sometimes firmly encapsulated with fibrous tissue, contains pus cells, granular detritns, and many readily stained and wellformed tubercle bacilli, together with involution forms. This pus, as above indicated, on inoculation into that most susceptible animal, the guinea-pig, gave negative results; no tuberculosis developed, which was to be expected if the 
cultures of the tubercle bacilli used for inoculation had been readily sterilized. We have further made cultures of this pus with a view of determining whether this suppuration might not be due to some of the ordinary progenic bacteria, but the results were negative. We thus find, in consonance with the results of Koch, and of Hueppe and Scholl, that dead tubercle bacilli are, under certain conditions, markedly pyogenic.

We have tested the chemotactic powers of sterilized cultures of the tubercle bacillus introrluced in tubes beneath the skin of rabbits, in the manner described in our first article, and found in every case after six days a plug of leucocytes extending deep into the broken end of the tube. We have introduced the dead cultures beneath the skin of rabbits inclosed between the laminæ of Ziegler's plates. In from three to five days the capillary space was found crammed with leucocytes. The dead tubercle bacillus thus possesses marked positive chemotactic powers.

Periloneal and Pleural Injections.-We next made injections of the emulsion of dead tubercle bacilli in considerable quantities ( 2 to 3 c. c. of a milky emulsion) into the peritoneal and pleural cavities-in four animals into the peritoneal cavity; in two, into the pleural cavity. We obtained one positive result in each set of injections. The others were all negative.

In the positive cases, whose results were similar in both the plcura and peritonæum, we found several larger and smaller white nodules adherent to the serous surfaces. These consisted of a central soft creamy mass, made up largely of pus cells with cell fragments and granular detritus intermingled with large and smaller clusters of readily stained and well-formed tubercle bacilli. While the nuclei of some of the pus cells were not readily stained by hematoxylin, there seemed to be no evidence of well-marked coagulation necrosis in the cells except when very large masses of the dead bacilli were introdnced. This central pus mass was in all cases closely surrounded and inclosed by a wall of fibrous tissue, in the inner layer of which were numerous larger and smaller masses of epitlelial cells intermingled with giant cells. Some of these epithelial and 
giant cell islets were irregular in shape and diffuse in outline. Others were sharply circumscribed and rounded, and presented the general appearances of miliary tubercles. Tubercle bacilli were everywhere abundant in these epithelial cell masses, and nowhere else in the fibrous wall of the nodules. Well-marked cheesy degeneration was nowhere seen in these cell masses which resemble tubercle tissue, even when the animal remained alive for four weeks after the injection.

We thus see that the injection of dead cultures of the tubercle bacilli is capable of occasionally inducing in the pleural and peritoneal cavity of the rabbit a suppurative focus and the formation about it of a tissue morphologically similar to tubercle tissue.

While these results are interesting, we should not forget that a great variety of substances, organized and unorganized, on introduction into the serous cavities, as well as beneath the skin, are capable of stimulating the cells of the part to the production of a new tissue which in many respects closely resembles in its morphological characters the tissue induced by living tubercle bacilli. The new tissue growths formed under these conditions have been the subject of the most extended research in times gone by. And every pathologist who lived through the epoch immediately preceding the discovery of the tubercle bacillus knows to what fallacious conclusions experimental studies on the introduction of foreign bodies into animals led many an observer, owing to the unwarrantable stress which was laid upon epithelioid cell tissue and giant cells, in determining the morphology of tubercle.

We have therefore left this line of experiment here and turned our attention to a form of experiment which seemed to promise a more direct insight into the detailed effects of dead tubercle bacilli upon living animal cells. This was the injection of the dead germs directly into the blood-ressels of the rabbit through the ear veins.

The leading idea in these experiments was to introduce into the body the dead bacilli under such conditions that their effects upon individual. cells could, if possible, be determined.

Intravenous Injections.-We have used in these experi- 
ments the sterile emulsions of tubercle bacilli descrubed above, and have injected them in moderate quantity, aiming to introduce into each animal an amount of the material which would correspond to a spheroidal mass of the solid culture of from about one to two millinetres in diameter, diffused in about two cubic centimetres of water. In order to avoid gross vascular disturbance, it is important to break up as much as is practicable the flocculent masses of the tubercle bacilli with a platinum needle before injecting them. The animals bear this injection into the blood perfectly well, and we have in our series of experiments in this way rarely observed that their general health was in any way impaired up to the third week, when a small proportion of the animals have died emaciated (five out of twenty-four). The animals were killed at intervals from the first day to the second month, as follows: 1st, $2 \mathrm{~d}, 5 \mathrm{th}, 8 \mathrm{th}, 10 \mathrm{th}, 17 \mathrm{th}$, $18 \mathrm{th}, 21 \mathrm{st}, 22 \mathrm{~d}, 25 \mathrm{th}, 26 \mathrm{th}, 27 \mathrm{th}, 28 \mathrm{th}, 32 \mathrm{~d}, 34 \mathrm{th}, 35 \mathrm{th}$, 48th, 60th day. The organs carefully hardened in strong alcohol, the lungs being filled through the trachea. Some of the sections were stained in the usual way with hematoxylin and eosin, while others were stained for tubercle bacilli. We have experimented in this way upon twentyfour rabbits.

We deem it best to give a summarized statement of our results, rather than a detailed account of the individual experiments, because the effects of the dead bacilli vary considerably, depending upon the amount introduced and the size and vigor of the animal, and in many other less welldefined ways.

If the animal is killed within twenty-four hours after the injection of a moderate amount of dead tubercle bacilli, the organs hardened in alcohol, and sections finally stained for tubcrcle bacilli, it will be found that the bacilli are present in by far the largest numbers, and in the largest masses in the capillaries of the lungs. They are next most abundant in the capillaries of the liver, and may be found in small numbers in the spleen.

After the first three or four days we have been unable to find bacilli in the spleen, bnt they appear to continue in approximately the same numbers in the lungs and liver as at first. We have made no examinations of the other 
viscera with a view of determining the presence or distribution of the bacilli in them.

We need only refer here to the experiments of Wyssokowicz (12) and others on the rapid disappearance of micro-organisms injected into the blood.*

Examinations of sectious of the organs of animals killed during the first and second week after the injection usually show that while the bacilli have largely disappeared from all the viscera, except the lungs and liver, they may still be found scattered singly or in small clusters in the smaller blood-vessels of these organs. Their situation can usually be best made out in the capillaries of the liver. Here they may be lying apparently free against the wall of the vessel, or they seem often to be surrounded by a small quantity of a nearly homogeneous or finely granular material which may be fibrin or blood plates, or, finally, they may lie singly or in small masses inclosed in variously shaped cells.

The earliest, and throughout the experiments the most constant, lesion which we have found as the result of the venous injection of dead tubercle bacilli is the development in the lungs of from one or two to innumerable small white nodules, some invisible to the naked eye, some as large as two or three millimetres in diameter. These small nodules may appear as early as the fifth day after the injection, and persist up to the end of the secoud month. In the earliest days they consist of a central denser mass made up of epithelioid and giant cells, interspersed with and often surrounded by masses of small spheroidal cells resembling leucocytes.

Readily stained tubercle bacilli are present often in large numbers in these lung nodules, especially in and among the epithelioid and giant cells. Such a nodule with its bacilli stained is represented in Fig. 1.

A limited area of lung tissue is replaced by these nodules, and the air-vesicles about them show an increase in the epitheliod cells, which sometimes completely fill them.

* The use of masses of dead tubercle bacilli in the study of multiple embolism would suggest itself as a mode of experimentation on this subject, since the differential staining enables us to locate the seat of lodgment of the emboli with much greater accuracy than is possible when small quantities of ordinary insoluble pigments are used. 
In animals killed at a later period these nodules are, as a rule, denser in texture, and consist largely of epithelioid cells and loose fibrous tisune (Fig. 2). Tubercle bacilli are now, as a rule, preseut in rerr small numbers.

These scattered nodules in the lungs are the only lesions which we have found up to the third week; no changes whatsoever having been found in any of the other viscera before this time.

Animals killed in from three to five weeks almost invariably show a considerable number, often a very large number, of the above-described white nodules in the lungs, so that they look like lungs in acute miliary tuberculosis. These nodules of new-formed tissue are usually much more easily seen after the lungs have been distended with alcohol and hardened than before. In many cases animals show no other gross lesions whatsuever, either in the kidney, spleen, or liver.

But if a microscopical examination of the liver is made, it will be found that in a considerable proportion of cases, as early as the third week after the injection, swollen endothelial cells are found in many of the capillaries, and scattered, often very numerons, islets of new-formed cells ramify in spreading clusters in the capillaries or form very minute circumscribed niasses, often consisting of but three or four cells with large nuclei and faintly granular bodies (Fig. 3). Sections showing these lesions and stained for tubercle bacilli show almost invariably one or more bacilli in these tiny new-formed cell masses. But free bacilli or bacilli inclosed in single cells are rarely to be found in the vessels, as they are in the first fortnight after the injections.

In most of the animals killed in from four to six weeks, in addition to the above described nodules in the lungs, the liver was more or less thickly bestrewn with minute whitish spots having the gross appearance of niliary tubercles. Microscopical examination of these livers shows that, in addition to these macroscopical lesions, there are microscopical lesions of sinilar character.

The simplest alteration that is found at these later periods consists in a proliferation of cells within the capillaries of the liver, so that these are moderately and diffusely di- 
lated in places, or distended, so as to contain branching nodules of epithelioid cells (see Fig. 4). It seems to us that these new cells in the capillaries are in part at least derived from the vascular endothelium (see Fig. 5).

Sometimes associated with this diffuse growth of new cells in the capillaries, sometimes withont it, the whole liver is thickly sprinkled with minute, sharply circumseribed, rounded nodules. Some of these nodules consist of epithelioid cells in part sharply outlined, but in pat tnerging into one another and intermingled with or surrounded by a zone of small spheroidal cells (Fig. 6).

Many of the small nodules, on the other hand, consist almost exclusively of small masses of epithelioid cells, either merged together as in Fig. 7, or loosely packed and distinct as in Fig. 8: Again, the nodules sometimes consist of a single small mass of epithelioid and giant cells, as in Fig. 9.

Finally, the liver nodules may be more complex in structure and consist of a cluster of larger and smaller epithelioid and giant-cell masses, as in Fig. 10. We have seen no evidence of proliferative changes in the liver cells; but these are sometimes squeezed and flattened by the growing nodules. So numerous are these small foci of cell proliferation that not infrequently from two to ten of them may be found within the area of a section of a single liver acinus. They are usually situated within the acinus, more rarely in the interlobular connective tissue.

In a large proportion of these liver nodules a varying number of tubercle bacilli can be found (Figs. 3, 7, 9, 10). But these become less and less abundant as time goes on after the injection, so that after from a month to six weeks we have found but a few scattered bacilli in most of the nodules, and in a considerable proportion none at all. The bacilli do not appear to bear any special relation to the giant cells, as they so of ten do in genuine miliary tubercles. They are often considerably broken and granular.

It is most noteworthy in this connection that the tubercle bacilli are much more abundant, as a rule, before and during the early stages of the growth of these cell masses than they are when these have assumed the more distinctly tubercular type. We have found no lesions whatsoever in 
any of the animals, in the kidners, and the tubercle-like masses but rarely in the spleen.

Our observations on the later stages of these new tissue growths are not ret complete enough to enable us to state what becomes of them when the animals are allowed to live. Up to the end of the seventh week we have seen no evidence of cheesy degeneration even in the largest and most complex of the nodules. It is perhaps owing to the lack of cheesy degeneration that the tubercle-like bodies are often first revealed by the microscopical examination.

We do not mean to draw fast lines in assigning definite periods at which these various lesions occur after injection of the dead bacilli, but only to indicate in a general way the arerages of our experiments.

We have never seen the slightest indication of the proliferation of the tubercle bacilli in the tissues of any of the injected animals.

The introduction of the dead tubercle bacilli in larger quantity and in as large masses as can be used withont killing the animals by multiple embolism leads to some strikingly different results from those which we have described; but this series of experiments is not yet completed and need not be further considered here.

Summary.-We have found that prolonged boiling, while often causing a considerable breaking up of the tubercle bacillus, does not interfere with its characteristic staining and does not alter the morphology of many of the individuals of a culture; so that bacilli killed in this way and introduced into the body can be readily recognized at their seat of lodgment, even after the lapse of many weeks.

O:ar experiments have shown that dead tubercle bacilli separatel from such of their metabolic products as are set free in the culture merlia or are extracted by prolonged boiling in water or fifty-per-cent. glycerin are capalle of inducing marked effects upon the body cells of the rabbit with which they are bronght in contact.

These dead tuhercle bacilli are markedly chemotactic. When introduced in considerable amount into the subcutaneous tissue or into the pleural or abdominal cavities, they are distinctly pyogenic, causing aseptic localized sup- 
puration. Under these conditions they are capable, moreover, of stimulating the tissues about the suppurative foci to the development of a new tissue closely resembling the diffuse tubercle tissue induced by the living germs.

We have found that dead tubercle bacilli introduced in small numbers into the blood-vessels of the rabbit largely disappear within a few hours or days, but that scattering individuals and clusters may remain here and there in the lungs and liver, clinging to the vessel walls for many days without inducing any marked changes in the latter. After a time, however, earliest in the lung; later, as a rule, in the liver; a cell proliferation occurs in the vicinity of these dead germs which leads to the formation of new multiple nodular structures bearing a striking norphological resemblance to miliary tubercles. There is in them, bowever, no tendency to cheesy degeneration and no evidence of proliferation of the bacilli, but rather a steady diminution in their number. It seems to us that the new structures originate in a proliferation of the vascular endothelium under the stimulus of the dear and disintegrating germs.

Control Experiments.-It will no doubt appear to others, as it did at first to ourselves, as if there must have been some experimental error in the attempts to kill the bacilli, so singular are the results that we have obtained. But we think that the treatment to which the bacilli used in these experiments have been subjected, together with the tests of death to which we have exposed them, make it evident that we have actually used dead germs for our injections.

This would appear certain, not only from the tests which we have detailed above, but also from the fact that we have made fresh boilings for each set of experiments (twelve in number), and in most cases have prolonged the boiling for from one to three hours beyond the period which has been established as fatal to these germs. It should be remembered that, according to the researches of Schill and Fischer (13), the action of moist heat at $100^{\circ} \mathrm{C}$. for fifteen minutes suffices to kill tubercle bacilli.

The question now arises whether these curious effects of dead tubercle bacilli upon the living tissues of the rabbit are due to some special peculiarity of the bodies of these 
particular germs, or may be induced by other dead germs or other substances introduced in the same way.

To satisfy oúrselves on this point, we have made a series of intravenous injections in approximately similar amounts of boiled cultures of the Bacillus diphtherice of Loeffler (six animals); of the Bacillus coli communis (five animals); of the Staphylococcus pyogenes aureus (six animals); of wheat flour (two animals); and of red pepper (two animals). These substances lave been introduced aseptically. The details of these control experiments need not be given here, since in none of them were there any alterations in any way comparable to those so nearly uniformly induced by the dead tubercle bacilli, and in most of them there was no reaction or change at all.

The animals under experiment were strictly isolated and kept under favorable hygienic conditions, so that the possibility of a chance tuberculosis is largely barred out.

We must therefore conclude that the lesions cansed by the introduction of dead tubercle bacilli into the body of rabbits are due to some peculiar property of the bodies of this species of germ.

Remarks.-Two possibilities, at least, exist as to this peculiar power of these dead tubercle bacilli. It may, of course, possibly be due to some trace of poison elaborated in the germ cell during its life and not given up in the culture medium, or extracted by boiling in water or dilute glycerin. Or, which seems more probable to us, in view of the peculiar properties which the bacterio-protein of other species of germs has been recently shown to possess, the remarkable power of these dead germs may be due to the specific proteid of the germ cells, which is gradually set free as the gerıns disintegrate at their seat of lodgment in the tissues.

Though we have made repeated attempts to isolate the bacterio-protein from the tubercle bacilli by the method of Necki, neither with this nor with any other method liave we succecded.

It seems to us highly probable that the bacterioprotein of the tubercle bacillus, either living or dead, when set free by disintegration in the tissues, is capable of furnishing that local cell stimulus which results in the forma- 
tion of the varions phases of those structures which we call tubercles and tubercle tissue. The slow growth of these structures would correspond to the exceptional structural invulnerability of the tubercle bacillus.

These structures, which, as we have shown, we can induce at will in the rabbit by the injection of dead tubercle bacilli into the blood-vessels, are morphologically absolutely typical of certain phases of miliary tubercles, even to the presence of stainable tubercle bacilli in them. Miliary tnbercles these structures are, but-and this is of vital importance-the animals do not acquire tuberculosis. It is not an acute infectious disease which we thus impart; there are no living germs to grow. The disease, if it is a disease, is not indefinitely progressive. The dead bacilli seem to act as foreign bodies simply, curiously stimulating, it is true, but only dead foreign bodies after all.

There is no tendency that we can observe in these tiny nodules to cheesy degeneration.

So far as we can see at present, when the limited amount of stimulant or poison, proteid or other, which they contained when we put them into the animal, is used up, the active process is over, and it rests with the recuperative powers of the animal to make what disposal they can of the local ravages which have been caused.

The drawings of the liver of rabbits injected through the veins with living tubcrcle bacilli by Yersin (14) show at a glance the essential difference between the genuine miliary tubercle of tuberculous rabbits and the non-infectious aseptic tubercles of our experiments-namely, the actively proliferating tubercle bacilli which make the lesion in the first case a progressive one, and which, sooner or later, cause the death of the animal.

These stndies would suggest the possibility that the formative tissue changes which are characteristic of tuberculosis in man may be largely due to the action of the bacterio-protein of the tubercle bacillus set free as the germs die and disintegrate in the tissues, while, on the other hand, the equally important and in some ways more characteristic action of the germ-namely, the coagulation necrosis, and possibly some of the vascular changes and other poisonous effects-may be chiefly induced by those freed 
metabolic products of the life processes of the germ which the experiments of Korh have recently brought to light, or to others as yet unknown.

We resist the temptation to elaborate here the many fascinating possibilities which these studies suggest as to the rationale of tubercular inflammation in man, and the closer analysis of its lesions which may be possible in the future.

If the results of our experiments are confirmed by others, it is evident that our conception of the significance of the various lesions of tuberculosis may be considerably modified and the therapentic possibilities made essentially clearer. It will be quite comprehensible why so many welldefined miliary tubercles, so many masses of tubercle tissue, so many destructive lesions of chronic phthisis, and so many so-called scrofulous and tubercular lymph nodes fail to show the presence of tubercle bacilli if it is established that the morphological characteristics of these structures are dependent upon the disintegration of the bacilli which once found lodgment where they form.

We are aware of the danger of drawing far-reaching inferences from a single series of experiments. But we think that we are fairly justified, from the experimental data now set forth, in the conjecture that we may have here the explanation of the comparatively slow growth of tubercle and tubercle tissue which is observed under a variety of conditions.

One may conjecture, too, whether a certain number of the miliary tubercles which we find in the body after a generalization of the tubercular process from an old tubercular focus may not actually be innocuous growths, or at least harmful only as foreign bodies in the tissues where they develop.

The possibility would, furthermore, suggest itself that those dense masses of fibrous tissue in the lungs which we usually regard as cvidence of healed tuberculosis may actually be innocuous, even though they harbor stainable tubercle bacilli, and no longer capable of lighting up a fresh infection, as is commonly supposed.

One may legitimately query, too, whether in the closer analysis of the tubercular processes in the future we may 
not find that the formation of the new tissue, the development of the tubercles themselves, is, after all, an attempt at a conservative process on the part of the organism incited by the stimulus of the disintegrating bodies of some of the germs. It may be, too, that, as Hueppe suggests, the conservative attempt is often rendered futile by a destructive tendency-cheesy degeneration-developed nuder the infinence of a metabolic product of the living and growing germs which the tubercular foci still harbor. The bearing of this possibility upon the administration of large doses of Koch's tubereulin should not, perhaps, be wholly ignored even at this stage of our knowledge.

It is somewhat curious to notice how closely in accord with some of our experimental results are many of the features of Hueppe's (15) recent essay to develop a rational explanation on theoretical gronnds of the varied phases of the development of tubercles and tuberculosis.

We wish, in conclusiou, to call renewed attention to the fact, too often overlooked, that the acute infectious diseases are much more complex, both in their lesions and their ætiology, than we are wont to realize. We were formerly perforce content when we had done what we could to make plain the morphologs of their obvious lesions. Light dawned at last on the relationship of bacteria to some of these diseases, and the definite establishment of the constant and inevitable relationship between some specific germ and its special disease was at first so satisfying that this relationship alone was regarded as a solution of its ætiology.

But the restless seeker after detail was not long content with this, and new light was speedily forthcoming as to the important rôle which chemical poisous, elaborated by pathogenic germs, had to play in the induction of the varied phenomena of this class of diseases. We have seen that a new phase of our knowledge is being now developed in the study of the proteid ingredients of the germ bodies.

But beyond all these lines of study and essential to their full fruition is the development of a fuller comprehension of the powers and reactions and idiosyncrasies of the body-cells themselves, upon whose comportment in the last analysis depend the distinctive features and the ultimate significance of the acute infections diseases. 
Thus the harvest garnered in this newly opened field of thought and research must ultimately be brought home to the old storehouse of pathological anatomy and physiology before it can be made in the fullest degree available for the understanding and curtailment of bacterial disease.

1. Prudden. New York Hedical Journal, Jüne 6, 1891.

2. Hammerschlag. Rev., Ctrlbl. f. Bacteriologie, etc., March 2, 1891, p. 272.

3. Hueppe and Scholl. Berlin. klin. Wochenschr., 1891, Jan. 26, Feb. 23, March 16, March 23.

4. Trudeau. Medical Record, Nov. 22, 1890.

5. Zulzer. Berlin. klin. Wochenschr., 1890. No. 4.

6. Crookshank. Lancet, Feb. 27, 1891, p. 300.

7. Weyl. Deutsch. med. Wochenschr., Feb. 12, 1891, p. 256.

8. Maffucci. Ctrlbl.f. allg. Path.. etc., Dec. 15, 1890.

9. Wyssokowicz. Mitth. a. Dr. Bremer's Heilanstalt, u.s.w., neue Folge, 1890.

10. Koch. Reprint, Medical Record, Jan. 17, 1891, p. 85.

11. Hueppe and Scholl. Berlin. klin. Wochenschrift, Jan. 26,1891, p. 89.

12. Wyssokowicz. Zeitsehrift für Hygiene, Bd. i, p. 3.

13. Schill and Fischer. Mitth. a. d. kaiserl. Gesundheitsumte, Bd. ii.

14. Yersin. Annales de l'Institut Pasteur, 1888, p. 140.

15. Hueppe. Berlin. Klin. Wochensehr.. March 23, 1891. 



7."

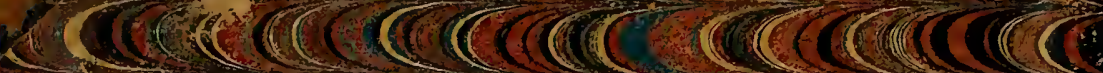

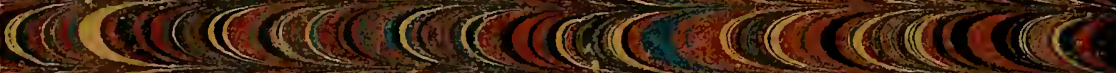

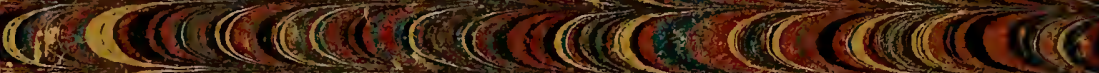

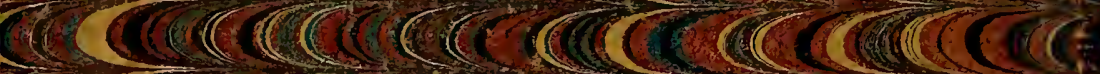

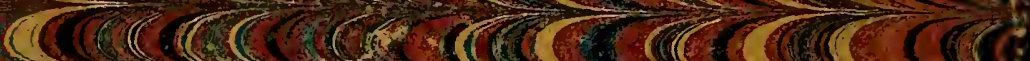

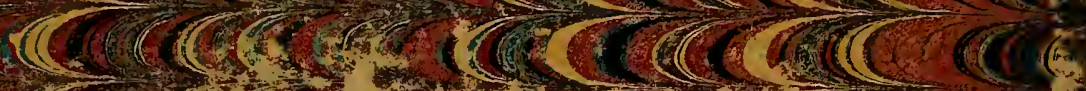

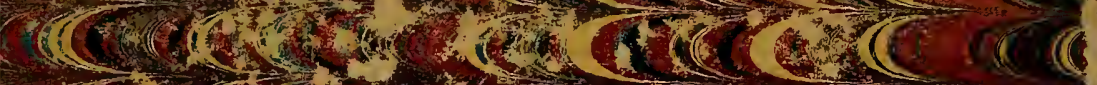

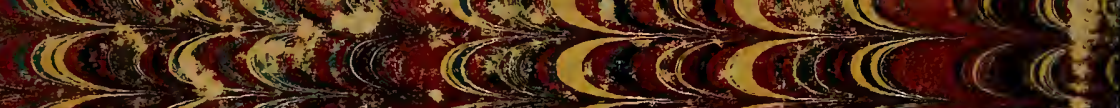

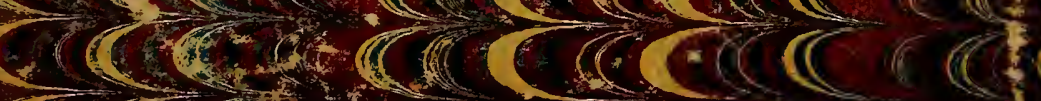

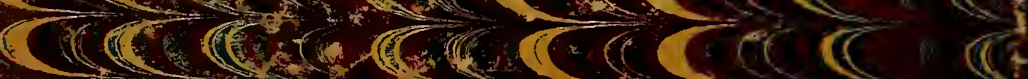

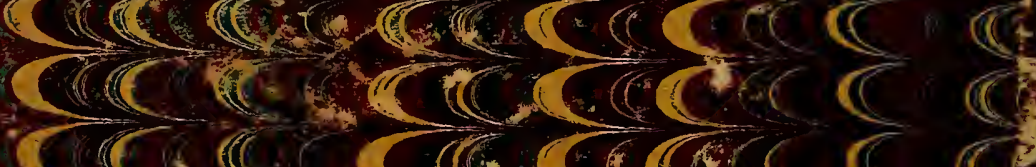

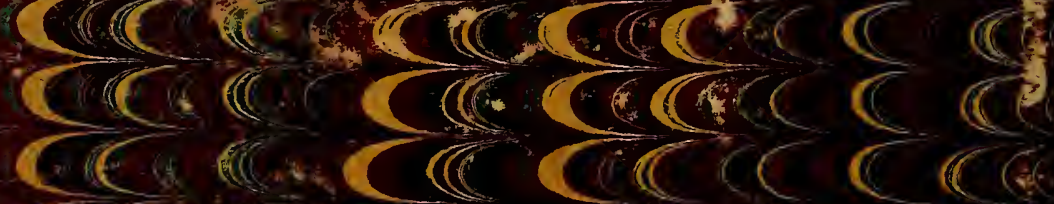
$\cos C 0$ C cer (a)
$\left(\mathbb{C}+\mathrm{C}^{2}\right.$

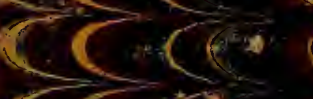

ace (is)

(i)

C $\mathbb{C}$

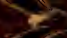

Ci. C)

C.C. (C)

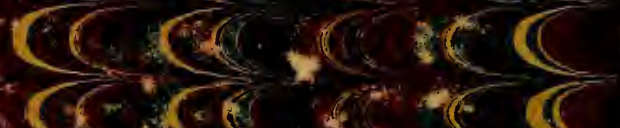
$\frac{C+6}{\cos } \times \frac{1}{C}$ $\times+\frac{C}{4}$ $\mathbb{C}\left(\mathbb{C}^{*}\right.$ C $(2)$

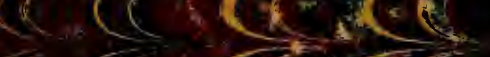
(4) C C C

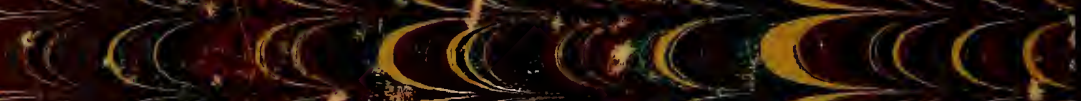
scacerar $\rightarrow$ CE C $\sin : 0<$ Cocior Co.se CC(C) 15@@ 63 (3) $(\mathrm{C})$

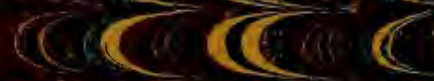
c) बC. 18.

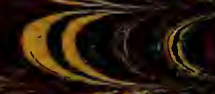

